\title{
CORRELATION OF THE HEAT-TRANSFER COEFFICIENT AT SPRINKLED TUBE BUNDLE
}

\author{
KORELACIJA KOEFICIENTA PRENOSA TOPLOTE PRI \\ POTRESENEM SNOPU CEVI
}

\author{
Petr Kracík, Ladislav Šnajdárek, Martin Lisý, Marek Baláš, Jiří Pospíšil \\ Brno University of Technology, Institute of Power Engineering, Faculty of Mechanical Engineering, \\ Technická 2896/2, 61669 Brno, Czech Republic \\ kracik@fme.vutbr.cz \\ Prejem rokopisa - received: 2014-07-23; sprejem za objavo - accepted for publication: 2015-07-08
}

doi:10.17222/mit.2014.115

\begin{abstract}
The paper presents a research on the heat-transfer coefficient at the surface of a sprinkled tube bundle, using a boiling simulation. A tube bundle consists of thirteen copper tubes divided into two rows and it is located in a low-pressure chamber where vacuum is generated by an exhauster via an ejector. The liquid tested was water at the absolute pressure in the chamber of $96.8-12.3 \mathrm{kPa}$ and at a thermal gradient of $55-30{ }^{\circ} \mathrm{C}$ between the cooled liquid flowing upwards inside the exchanger and the heated falling film liquid. The flow of the falling film liquid ranged from $0-17 \mathrm{~L} / \mathrm{min}$. Two types of tubes were tested, a smooth one and a sandblasted one. The correlation of the average heat-transfer coefficient at the surfaces of both tube types was identified.

Keywords: sprinkled, water, under-pressure, heat transfer
\end{abstract}

Članek predstavlja raziskavo koeficienta prenosa toplote na površini potresenega snopa cevi s simulacijo vrenja. Snop cevi sestoji iz trinajstih bakrenih cevi, razporejenih v dve vrsti in se nahaja v nizko tlačni komori, kjer se ustvarja vakuum s pomočjo aspiratorja preko ejektorja. Preizkusna tekočina je bila voda pri absolutnem tlaku v komori med $96,8 \mathrm{kPa}$ do $12,3 \mathrm{kPa}$ in toplotnim gradientom $55^{\circ} \mathrm{C}$ do $30^{\circ} \mathrm{C}$ med ohlajeno tekočino, ki je tekla znotraj izmenjevalca navzgor in padajočo tanko plastjo segrete tekočine. Tok padajoče tekočine je bil med $0 \mathrm{~L} / \mathrm{min}$ in $17 \mathrm{~L} / \mathrm{min}$. Preizkušeni sta bili dve vrsti cevi, gladka in peskana. Postavljena je bila korelacija povprečnega koeficienta prenosa toplote na površini obeh vrst cevi.

Ključne besede: posuto stanje, voda, podtlak, prenos toplote

\section{INTRODUCTION}

On a horizontal tube bundle sprinkled with a liquid at a low flow rate, a thin liquid film is formed that facilitates an effective heat transfer. The liquid flowing through the bundle may form three basic sprinkle modes visible in Figure 1. These are: a) the droplet mode, b) the jet mode and c) the membrane (sheet) mode. ${ }^{1}$

The transition from the droplet into the jet mode is defined with at least one stable water column among the droplets. The transition from the jet into the membrane mode is defined with the columns' connections and their creation of small triangular sheets. In this mode, columns and sheets exist side by side. The type of mode depends
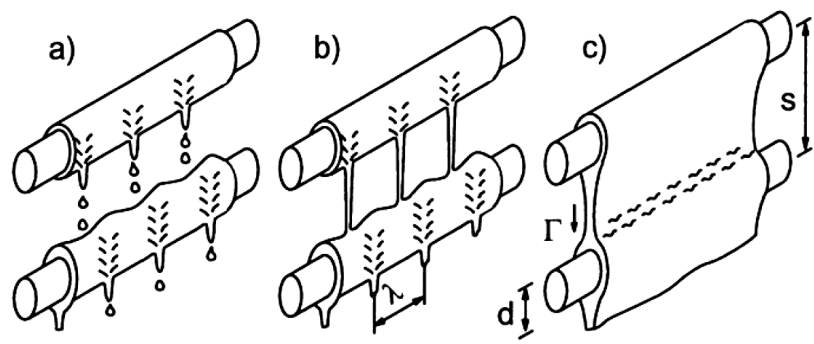

Figure 1: Sprinkle modes: ${ }^{1}$ a) droplet, b) jet, c) membrane Slika 1: Načini potresenja: ${ }^{1}$ a) kapljica, b) curek, c) zavesa mainly on the tube pitch at a horizontal tube bundle, the flow rate and physical properties of the liquid.

\section{ANALYSIS}

This paper presents the results of the heat-transfer coefficient at the surface of a sprinkled tube bundle situated in a low-pressure environment, where the water flowing outside the bundle has not yet reached the boiling point. For the practical use of the experimental results and their generalisation for a wide range of operational parameters, Chun and Seban ${ }^{2}$ suggested the mathematical dependence of the Nusselt number $(\mathrm{Nu}[-])$ on the Reynolds number $(\operatorname{Re}[-])$ that expresses the fallingfilm-liquid flow, the Prandtl number $(\operatorname{Pr}[-])$ that is functionally dependent mainly on the falling-film-liquid temperature and the pressure in the surroundings of the liquid, and, in the case that the surface of the sprinkled tube boils, it also includes the thermal flow density. The Nusselt number for a non-boiling liquid can be generally defined as:

$$
N u=\alpha_{0} \cdot \sqrt[3]{\frac{v^{2}}{g \cdot \lambda^{2}}}=a_{1} \cdot \operatorname{Re}^{a_{2}} \cdot \operatorname{Pr}^{a_{3}}
$$


where $\alpha_{\mathrm{o}}\left[\mathrm{W} \mathrm{m} \mathrm{m}^{-2} \mathrm{~K}^{-1}\right]$ is the heat-transfer coefficient at the sprinkled tube surface, $v\left(\mathrm{~m}^{2} \mathrm{~s}^{-1}\right)$ is the kinematic viscosity, $g\left(\mathrm{~m} \mathrm{~s}^{-2}\right)$ is the gravitational acceleration, $\lambda$ $\left(\mathrm{W} \mathrm{m} \mathrm{m}^{-1} \mathrm{~K}^{-1}\right)$ is the thermal conductivity and the values $a_{1}$ to $a_{3}$ are empirically derived constants.

W. H. Parken et al. ${ }^{4}$ published the results of their experiments where they always sprinkled one brass, electrically heated tube. The experiments were conducted in the temperature range of the falling film liquid between $49{ }^{\circ} \mathrm{C}$ and $127{ }^{\circ} \mathrm{C}$, in an input range of $30-80$ $\mathrm{kW} / \mathrm{m}^{2}$ and at a falling-film-liquid mass flow related to the tube length $(\Gamma)$ of $0.135-0.366 \mathrm{~kg} /(\mathrm{s} \mathrm{m})$. The measured data for water that was not boiling at the tube surface were used to derive empirical equations for the average heat-transfer coefficient for tube diameters of $25.4 \mathrm{~mm}(1 ")$ and $50.8 \mathrm{~mm}(2 ")$ based on Equation (1):

$$
\begin{aligned}
& \alpha_{0}=0.042 \cdot \sqrt[3]{\frac{\lambda^{3} \cdot g}{v^{2}}} \cdot\left(\frac{4 \Gamma}{\mu}\right)^{0.15} \cdot\left(\frac{v}{a}\right)^{0.53} \\
& \alpha_{0}=0.038 \cdot \sqrt[3]{\frac{\lambda^{3} \cdot g}{v^{2}}} \cdot\left(\frac{4 \Gamma}{\mu}\right)^{0.15} \cdot\left(\frac{v}{a}\right)^{0.53}
\end{aligned}
$$

where $\mu$ (Pa s) is the dynamic viscosity, $a\left(\mathrm{~m}^{2} \mathrm{~s}^{-1}\right)$ is the thermal diffusivity and the water properties were determined with the average temperature of the tube-wall temperature and the input falling-film-liquid temperature. When determining Equation (2) for the tube diameter of $25.4 \mathrm{~mm}$, the relative error reached seven percent and seven data points out of fifty-two deviated by more than $10 \%$. With Equation (3), derived for the tube diameter of $50.8 \mathrm{~mm}$, the relative error reached the maximum of $8 \%$.

W. L. Owens ${ }^{3}$ published the results of his research on the heat-transfer coefficient at the surface of one smooth stainless-steel tube of one- and two-inch diameters that was sprinkled with both water boiling at the tube surface and non-boiling water, in a Reynolds-number range of $120-10^{4}$ [-]. In comparison with K. R. Chun's and R. A. Seban's ${ }^{2}$ equations that already formed the basis for a derivation of the empirical dependencies of the abovementioned W. A. Parken and al. ${ }^{4}$, W. L. Owens reached the conclusion that the Nusselt number (or the heattransfer coefficient at the tube surface) is not, at all conditions, dependent on the Reynolds number. However, eventually he added to his equations the dimensionless ratio of the distance between the sprinkling and the sprinkled tube to the sprinkled-tube diameter, the total of this raised to the power of one tenth.

When assessing and determining the empirical dependence, W. L. Owens ${ }^{3}$ used dispersion diagrams, which proved the necessity of the extraction of the root of the Prandtl number by the second power, helping to achieve a linearization in relation to the rest of the parameters in the following equations of the Nusselt-number calculation with a relatively low value dispersion (all the equation deviations were determined at $10 \%$ ). The final empirical dependence of the heat-transfer coefficient of non-boiling water for the laminar mode lies in Equation (4) and for the turbulent mode in Equation (5):

$$
\begin{aligned}
& \alpha_{0, \text { lam }}=2.2 \cdot \sqrt[3]{\frac{\lambda^{3} \cdot g}{v^{2}}} \cdot\left(\frac{s-D}{D}\right)^{0.1} \cdot \frac{1}{\sqrt[3]{R e}} \\
& \alpha_{0, \text { tur }}=0.185 \cdot \sqrt[3]{\frac{\lambda^{3} \cdot g}{v^{2}}} \cdot\left(\frac{s-D}{D}\right)^{0.1} \cdot \sqrt{P r}
\end{aligned}
$$

where $s(\mathrm{~m})$ is the pitch pipe, $D(\mathrm{~m})$ is the tube diameter and the transition between these modes was determined by W. L. Owens ${ }^{3}$ in Equation (6):

$$
R e_{t r}=1.68 \cdot \frac{1}{\operatorname{Pr}^{1.5}}
$$

In the case of boiling occurring at the tube surface, Owens ${ }^{3}$ assumed a fully developed turbulent flow, for which the following heat-transfer-coefficient equation stands:

$$
\alpha_{0, \text { tur }}=0.175 \cdot\left(\frac{s-D}{D}\right)^{0.1} \cdot \sqrt[4]{\dot{q}} \cdot \sqrt{P r}
$$

Should the temperature of the tube wall be higher than the temperature of the saturated liquid flowing around the tube, although the liquid does not reach this temperature, the so-called undercooled boiling may occur. This generalised assumption can be deepened by the criterion that undercooled boiling can be viewed at the tube where the bubbles appear. The temperature at the bubble surface is higher or equal to the temperature of the saturated liquid, corresponding to the pressure inside the bubbles. This phenomenon was studied by Sernas ${ }^{5}$ who published the results of his experiments when he sprinkled, in each case, one brass electrically heated tube with water. Experiments were conducted in a falling-film-liquid temperature range of $44.9-117{ }^{\circ} \mathrm{C}$, in an input range of $47-79 \mathrm{~kW} / \mathrm{m}^{2}$ and a mass flow related to the tube length of $0.133-0.292 \mathrm{~kg} /(\mathrm{s} \mathrm{m})$. He derived empirical equations of the average heat-transfer coefficient for a tube of $25.4 \mathrm{~mm}$ (8) and $50.8 \mathrm{~mm}$ (9) diameters from the measured data:

$$
\begin{aligned}
& \alpha_{0}=0.1925 \cdot \sqrt[3]{\frac{\lambda^{3} \cdot g}{v^{2}}} \cdot \operatorname{Re}^{0.24} \cdot \operatorname{Pr}^{0.66} \\
& \alpha_{0}=0.1725 \cdot \sqrt[3]{\frac{\lambda^{3} \cdot g}{v^{2}}} \cdot \operatorname{Re}^{0.24} \cdot \operatorname{Pr}^{0.66}
\end{aligned}
$$

where the mean quadratic deviation equalled $3.1 \%$ at the smaller diameter and $3.3 \%$ at the larger diameter and only one point out of 33 exceeded such a deviation at the smaller diameter and 4 points out of 39 at the larger diameter, which makes about $10 \%$.

\section{EXPERIMENTAL DEVICE}

For the purposes of examining the heat transfer at sprinkled tube bundles, a test apparatus was constructed at the Brno University of Technology (Figure 2). The 


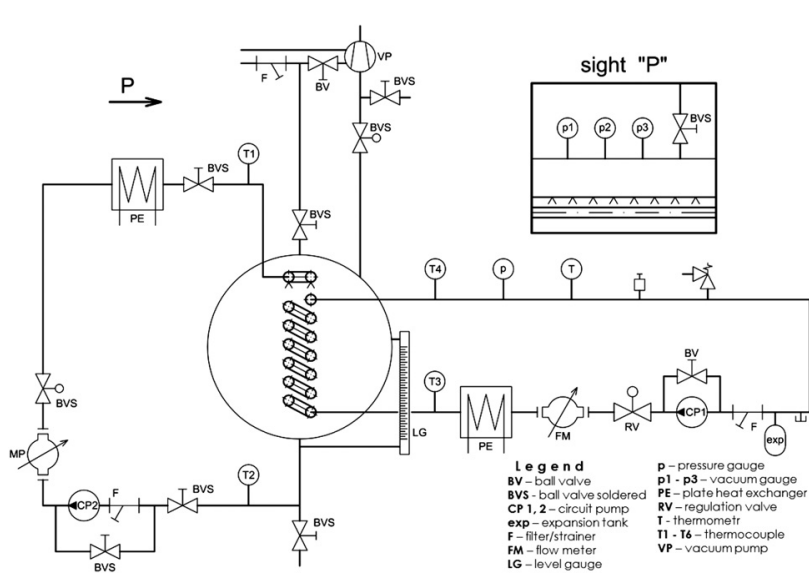

Figure 2: Low-pressure stand diagram

Slika 2: Diagram stanja pri nizkem tlaku

tube bundle, at which both boiling and condensation can be simulated, is placed in a vessel where a low pressure is created by an exhauster through an ejector.

The low-pressure stand chamber is a cylindrical vessel, $1.2 \mathrm{~m}$ in length, with three apertures, in which the tube bundle of an examined length of $940 \mathrm{~mm}$ is inserted. The tube bundle is installed in two fitting metal sheets, which define the sprinkled area. The bundle is divided into two rows and consists of 13 (7 and 6) copper tubes of a 12-mm diameter with a tube pitch of $25 \mathrm{~mm}$. The bundle is U-shaped and the flow in the loop is uninterrupted.

Two closed loops are connected to the chamber; a sprinkled one and a sprinkling one. The sprinkled loop is designed for an overpressure of up to $1.0 \mathrm{MPa}$ and it functions as a cooling/heating liquid conveyor. There are a pump, a regulation valve, a flow meter and a plate heat exchanger attached to both loops. The plate heat exchanger can be connected to a boiler or a gas boiler with hot water designated for the liquid heating-up or cooling water in the case of cooling. In order to enable visual control, the sprinkled loop also includes a manometer and a thermometer. The thermal status in individual loops is measured with wrapped unearthed T-type thermocouples on the agents' input and output from the vessel. There are three vacuum gauges measuring the low pressure. The first vacuum gauge is designed for the visual control and it is a mercury meter; the second digital vacuum gauge, Baumer TED6, enables the measuring within the whole desired low-pressure range, but it is less accurate with lower pressure values. To allow accurate measuring of the low spectrum, the third digital vacuum gauge with a range of $2.0-0 \mathrm{kPa}$ is used. The accuracy of the vacuum gauge, providing the results for the assessment, is $0.5 \%$ of the measured range, i.e., \pm $0.5 \mathrm{kPa}$.

Electromagnetic flow meters Flomag 3000 attached to both loops measure the flow rate. The measuring range of the flow meters is $0.0078-0.9424 \mathrm{~L} \mathrm{~s}^{-1}$, where the accuracy is $0.5 \%$ of the measured range, i.e., $\pm 0.00467 \mathrm{~L} \mathrm{~s}^{-1}$. All the examined quantities are scanned

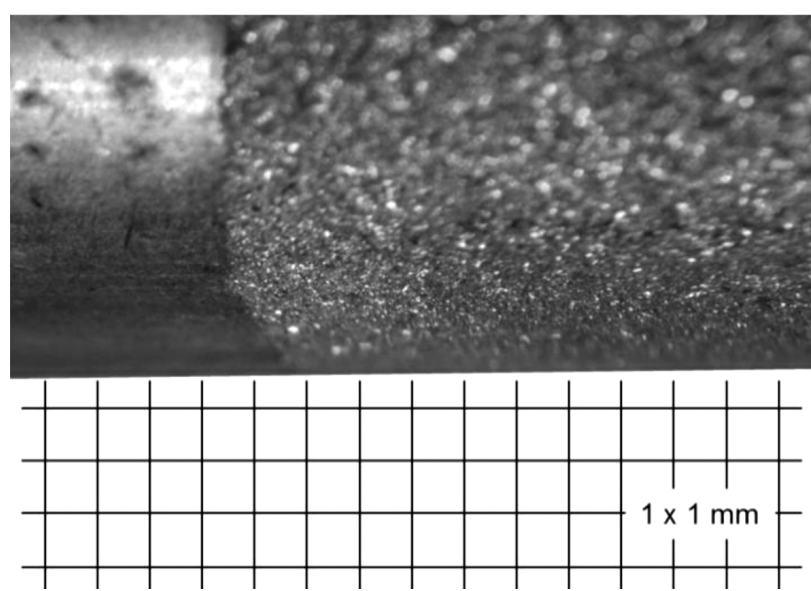

Figure 3: Sprinkled-tube surface types (smooth on the left and sandblasted on the right)

Slika 3: Vrsta površine na cevi (gladka na levi in peskana na desni)

with a frequency of $0.703 \mathrm{~Hz}$, using measuring cards DAQ 56 either directly (thermocouples) or via transducers.

Apart from the influence of the sprinkled and sprinkling temperature media, the absolute pressure in the vessel and the medium flow for the studied heat-transfer coefficient at the tube surface, the influence of the tube surface type is also investigated. The illustration of the tested tube surfaces can be found in Figure 3. The sandblasted surface was treated with a blast-furnace slag to make it coarser, but the reduction of the material was insignificant, so the effect of this technology modification is negligible.

The evaluation of the measured data is based on the thermal balance between the sprinkled and sprinkling loop according to the law of conservation of energy. The transferred heat comprises convection, conduction and radiation. At lower temperatures, the heat transferred by radiation is negligible; therefore, it is excluded from further calculations. The calculation of the studied heattransfer coefficient is based on Newton's heat-transfer law and Fourier's heat-conduction law.

\section{RESULTS}

The final dependence of the heat-transfer coefficient on the smooth tube surface is shown with blue points in Figure 4. In this mode, hot water flows inside the tubes with the average input temperature of $55.2{ }^{\circ} \mathrm{C}$, with a statistical deviation of four tenths of a degree and with the average flow rate of $12.4 \pm 0.5 \mathrm{~L} \mathrm{~min}^{-1}$. The exchanger is sprinkled with cool water with the average input temperature of $29.9 \pm 0.5{ }^{\circ} \mathrm{C}$ and the sprinkling-liquid flow rate ranges from $1.0 \mathrm{~L}$ to $15.8 \mathrm{~L} \mathrm{~min}^{-1}$. This mode was tested at a pressure level of $96.8-12.9 \mathrm{kPa}$ (atmospheric pressure at the time of measurement). The same diagram displays the dependence of the heat-transfer coefficient on the sandblasted tubes with red points. In this mode, the average temperature of the closed-loop input was $55.1^{\circ} \mathrm{C}$, having a statistical deviation of half a 


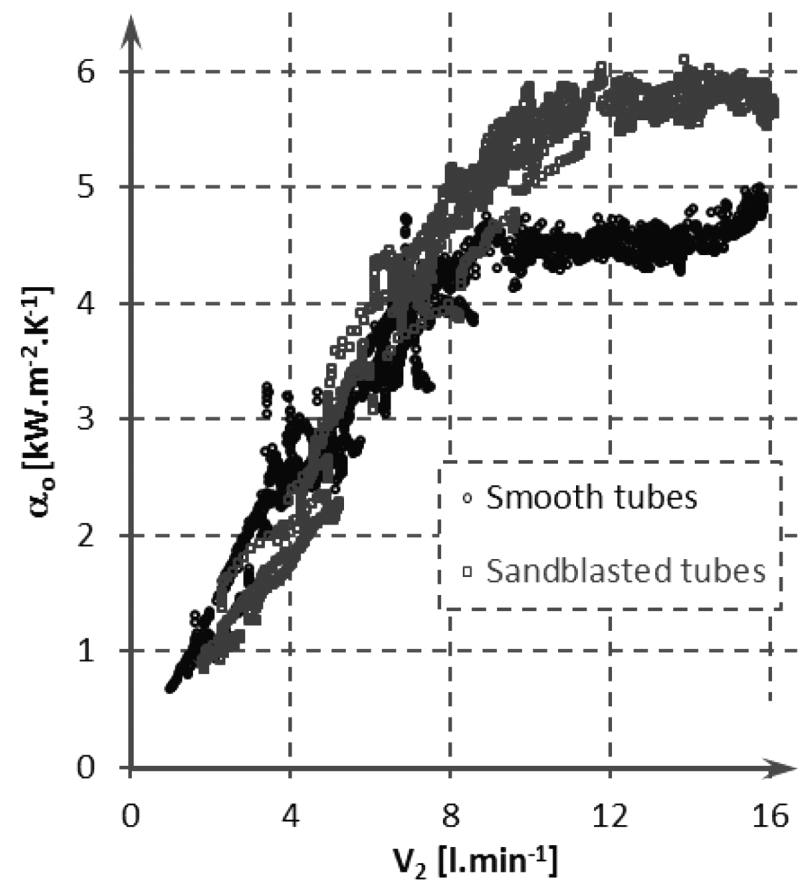

Figure 4: Dependence of heat-transfer coefficient on falling-filmliquid volumetric flow rate

Slika 4: Odvisnost koeficienta prenosa toplote od volumetrične hitrosti padajoče tekočine

degree and the average flow rate of $13.7 \pm 0.3 \mathrm{~L} \mathrm{~min}^{-1}$. The exchanger is sprinkled with cool water with the average input temperature of $29.8 \pm 0.5{ }^{\circ} \mathrm{C}$ and the sprinkling-liquid flow rate ranges from 1.8 to 16.1 $\mathrm{L} \mathrm{min}^{-1}$. This mode was tested at a pressure level of 96.7-12.3 $\mathrm{kPa}$ (atmospheric pressure at the time of measurement).

Considering the total sprinkled length, only the jet mode was achieved with the maximum flow rate. It changed into the droplet-jet mode at a flow rate of approximately $14.0 \mathrm{~L} \mathrm{~min}^{-1}$ and into the full droplet mode at a flow rate of approximately $6.0 \mathrm{~L} \mathrm{~min}^{-1}$ or below this value. Figure $\mathbf{4}$ clearly shows the final trends of the heat-transfer coefficient in dependence on the increasing falling-film-liquid volumetric flow rate and the convenience of individual surface types. Up to a flow rate of approximately $5.0 \mathrm{~L} \cdot \mathrm{min}^{-1}$ the smooth surface is more convenient, as smooth tubes enable the heat-transfer coefficient to improve by at least $45 \%$. In a flow-rate range of approximately $5.0-7.0 \mathrm{~L} \mathrm{~min}^{-1}$ no surface proves better, and at a flow rate of $9.0 \mathrm{~L} \cdot \mathrm{min}^{-1}$ and higher the sandblasted surface is more convenient. The difference against the smooth surface is up to $22 \%$. The measuring-device error recalculated into the heat-transfer coefficient fluctuated around the average value of $3.8 \%$ for the smooth tubes and around $5.3 \%$ for the sandblasted tubes.

For the purpose of a comparison with the other authors, analogy criteria and the functional dependence between them were used, as visible on Figure 5, where the points indicating "smooth", including the curve connecting the points, stand for the resulting Nusselt number, which is the function of the Reynolds number and it is derived from the first section of Equation (1). The same applies to the points indicating "sandblasted". The average measuring-device error related to the heattransfer coefficient at the tube-bundle surface is displayed at individual points; it is recalculated into the Nusselt number and it is the same, in relative values, as for the heat-transfer coefficient. This figure does not display all the measured points, but only the above-mentioned selected points. Status variables used in the equations defined by other authors and displayed in the same figure were taken from these particular points.

The results of the measurement are compared with two other authors and one author team. The first comparison is with Parken et $a .^{4}$, displaying the points (a) for the tube diameter of $25.4 \mathrm{~mm}$ according to Equation (2) and the points (b) for the tube diameter of $50.8 \mathrm{~mm}$ according to Equation (3). Another comparison is with Sernas ${ }^{5}$, displaying the points for the same diameters according to Functions (8) and (9). The last author whose points are included in the figure is Owens ${ }^{3}$, who defined the functions for various diameters, i.e., the functions for a laminar and a turbulent flow. With respect to the high Prandtl number, with which the transit Reynolds number is determined according to Equation (6), the case is considered to be a turbulent flow in the entire measured range. Therefore, the points are displayed according to Equation (5). The points are connected by a conveniently selected curve to highlight the trend.

Figure 5 presents two major intersections of the given waveforms with the compared curves. The values

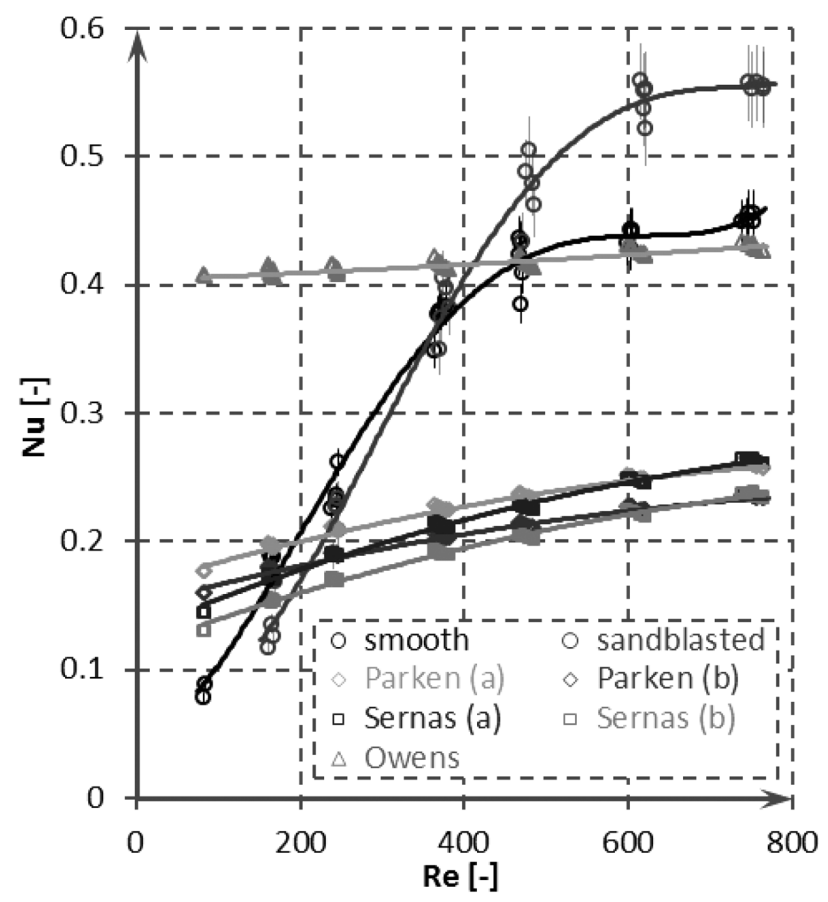

Figure 5: Comparison of obtained results with other authors

Slika 5: Primerjava dobljenih rezultatov z rezultati drugih avtorjev 
of the first one are determined according to Parken and Sernas, in a Reynolds number range of approximately $150-240$, i.e., a Nusselt-number range of $0.08-0.17$, and the values of the second one are displayed according to Owens, in a Reynolds-number range of approximately 410-470, where the Nusselt number is approximately 0.42 .

The functions according to Parker and Sernas were determined for the mass flow related to a length unit from $0.135 \mathrm{~kg} \cdot \mathrm{s}^{-1} \cdot \mathrm{m}^{-1}$, which corresponds to the end of the studied Reynolds number range. The function defined by Owens, calculated with the value of the outer tube diameter of $12.0 \mathrm{~mm}$, covers approximately $40 \%$ of the studied volumetric flow-rate range, in which the correspondence with the results for the smooth tubes is quite strong, starting already at the value of the Reynolds number of 380 .

Criterial functions were derived for the whole statistical collection of the measured data for the bundles of smooth or sandblasted tubes. When determining the criterial equation, the recommended Chun's and Seban's ${ }^{2}$ Equation (1) was not effective, although it is most frequently applied by many authors. Within the regression analysis the given trend was best expressed with a linear combination of power functions:

$N u=\alpha_{0} \cdot \sqrt[3]{\frac{\mu^{2}}{g \rho^{2} \lambda^{3}}}$

$N u=a+b \cdot(R e)^{\mathrm{c}}+d \cdot(R e)^{\mathrm{e}}+f \cdot(R e)^{\mathrm{g}}+h \cdot(\operatorname{Pr})^{\mathrm{i}}$

where coefficients c, e, g, i were estimated on the basis of the function parameters and the other coefficients were calculated with a statistical software. All the coefficients for the smooth and sandblasted tubes are given in Table 1.

Table 1: Coefficients for equation (10)

Tabela 1: Koeficienti za enačbo (10)

\begin{tabular}{|c|c|c|c|c|c|}
\hline & $a / b$ & $c / d$ & $e / f$ & $g / h$ & $i$ \\
\hline \multirow{2}{*}{ Smooth } & 1.5344 & 1.35 & 5.3 & 4.8 & 0.3 \\
\cline { 2 - 6 } & 0.000134 & $1.992 \cdot 10^{-15}$ & $-6.332 \cdot 10^{-14}$ & -0.9692 & \\
\hline \multirow{2}{*}{$\begin{array}{c}\text { Sand- } \\
\text { blasted }\end{array}$} & 2.4086 & 1.48 & 3.2 & 0 & 0.3 \\
\cline { 2 - 6 } & 0.000066 & $-3.6894 \cdot 10^{-15}$ & 0 & -1.547 & \\
\hline
\end{tabular}

Both forms of derived equation were tested comparatively against the originally calculated values of the Nusselt number; in the case of smooth tubes, it was 2483 points. For this statistical collection, a relative error of $4.25 \%$ and a relative mean quadratic deviation of $4.72 \%$ were set; they are below $5 \%$ that is generally considered as the limit for a well-defined regression function. In the case of sandblasted tubes, 1874 points were measured (calculated) which, in comparison with the derived function, showed a relative error of $4.50 \%$ and a relative mean quadratic deviation of $4.63 \%$, which are also below the $5 \%$ limit.

\section{CONCLUSIONS}

This paper presents a research on the heat-transfer coefficient at the surface of a sprinkled tube exchanger where the falling film liquid was heated. This tube bundle was tested in a low-pressure chamber, in a pressure range of $96.8-12.3 \mathrm{kPa}(\mathrm{abs})$ and at a thermal gradient of 55-30 ${ }^{\circ} \mathrm{C}$ with various falling-film-liquid flow rates. Two different types of the tube-bundle surface were studied, i.e., a smooth one and a sandblasted one, while the geometries of the heat exchangers were identical. Correlations of the mean heat-transfer coefficient at the tube surface were determined for both heat-exchanger types and these were compared with the other authors who conducted research on the heat-transfer coefficient in a sprinkled tube with water as the falling film liquid that did not reach the boiling point.

When comparing the results with the other authors, it is necessary to consider the difference as merely orientational, due to the following reasons. The studied tube bundle was made of copper tubes with a $12 \mathrm{~mm}$ diameter and the total bundle length of $12.22 \mathrm{~m}$. The other authors studied the heat-transfer coefficient at a single short smooth tube with a 1-m length, and 1" and 2" diameters; in Sernas and Parken's case, the tubes were made of brass and in Owens's case, they were made of stainless steel. In spite of that, a significant correspondence of the Nusselt number occurred in the case of the tube bundle with a smooth surface where the Reynolds number was higher than approximately 400 [-].

\section{Acknowledgment}

The presented results were obtained in the frame of project NETME CENTRE PLUS (LO1202), created with the financial support from the Ministry of Education, Youth and Sports of the Czech Republic under the National Sustainability Programme I.

\section{REFERENCES}

${ }^{1}$ R. Armbruster, J. Mitrovic, Evaporative cooling of a falling water film on horizontal tubes, Experimental Thermal and Fluid Science, 18 (1998) 3, 183-194, doi:10.1016/S0894-1777(98)10033-X

${ }^{2}$ K. R. Chun, R. A. Seban, Heat Transfer to Evaporating Liquid Films, Journal of Heat Transfer, 93 (1971) 4, 391-396, doi:10.1115/ 1.3449836

${ }^{3}$ W. L. Owens, Correlation of thin film evaporation heat transfer coefficients for horizontal tubes, Proceedings of the Fifth Ocean Thermal Energy Conversion Conference, Miami Beach, Florida, 1978, 71-89

${ }^{4}$ W. H. Parken, L. S. Fletcher, V. Sernas, J. C. Han, Heat Transfer Through Falling Film Evaporation and Boiling on Horizontal Tubes, Journal of Heat Transfer, 112 (1990) 3, 744-750, doi:10.1115/ 1.2910449

${ }^{5}$ V. Sernas, Heat Transfer Correlation for Subcooled Water Films on Horizontal Tubes, Journal of Heat Transfer, 101 (1979) 1, 176-178, doi:10.1115/1.3450913 